підтримки процесу навчання системою супроводу в межах якої активно застосовується комп'ютерна техніка, що оснащена СІТА. Це дозволить досягнути очікуваного результату, який полягає в формуванні інформаційно-комунікативної компетентності людей з депривацією зору через оволодіння інформаційними та фаховими знаннями, вміннями та навичками використовувати комп'ютерну техніку у процесі здійснення соціальної та професійної діяльності.

Окреслені підходи створюють передумови для визначення цілей, змісту, методів та засобів навчання в системі професійної комп'ютерної підготовки осіб з порушеннями зору.

\title{
Література
}

1. Кольченко К. О. Забезпечення інклюзії молоді з інвалідністю в університетське середовище / К. О. Кольченко, Г.Ф.Нікуліна // Актуальні проблеми навчання та виховання людей з особливими потребами : [зб. наук. праць]. - № 6 (8). - К. : Університет «Україна», 2009. - С. 10-15.

2. Инклюзивное образование: методология, практика, технологии : [материалы международной научно-практической конференции (20-22 июня 2011, Москва)] / Моск. гор. психол. пед. ун-т; редкол.: С. В. Алехина и др. - М. : МГППУ, 2011. - 244 с.

3. Пономарев Я. А. Психология творчества / Я. А. Пономарев. - М. : Наука, 1976. - 302 с.

Стаття надійшла до редакції 14.05.2012 p.

УДК821.161.2.-3.09:378.147

Н. В. Романишина, докторант, Національний педагогічний університет ім. М. П. Драгоманова

\section{МЕТОДИКА ФОРМУВАННЯ У СТУДЕНТІВ-ГУМАНІТАРІЇВ ПИСЬМЕННИЦЬКОЇ КОМПЕТЕНТНОСТІ}

Романишина Н.В. Методика формування у студентів-гуманітаріїв письменнищької компетентності.

Автором статті подано методичні рекомендачіï, у яких запропоновано у процесі практики написання твору малої прозової форми виявляти і розвивати у майбутніх учителівсловесників літературне обдарування, вміння віднаходити нюанси мистецької реалізації, долаючи деструктивний автоматизм, стихійне наслідування стилю мития-професіонала.

Ключові слова: письменницька компетентність, текстотворчі вміння, креативність мислення, фантастичний жанр.

Романишина Н. В. Методика формирования у студентов-гуманитариев писательской компетенции.

Автор статьи представляет методические рекомендации, в которых предлагается 6 прочессе практики написания сочинения малой прозаической формы находить и развивать в будущих учителях словесности литературные задатки, умения искать отдельные нюансы артистической реализачии, преодолевая деструктивный автоматизм, слепую и стихийную имитацию стиля писателя-профессионала.

Ключевые слова: писательская компетентность, текстотворческие умения, креативность мышления, фантастический жанр.

Romanishina N.V. The methodics of the forming in students literary competence.

The author of the article offers methodological recommendations, how through the practice of writing short prose works to find and develop in future teachers of literature literary makings, the ability to search for the individual nuances of artistic realization, overcoming destructive automatism, blind and spontaneous imitation of the style of the writer-professional.

Key words: literary competence, textforming skills, creative thinking, fantasy genre. 
Постановка проблеми. Поміж нових педагогічних технологій, які впроваджуються у навчальний процес вищої педагогічної школи, зокрема задля підвищення ефективності майбутньої професійної діяльності випускників, актуальності набуває компетентнісне навчання. 3 компетентностями пов'язують формування нової парадигми результату освіти [2]; адже це ті «індикатори, які дозволяють визначити готовність/.../випускника до життя, його подальшого розвитку й активної участі в житті суспільства $[8$, с. 13]. На взаємозалежності «втілення ключових компетентностей» i «розвитку особистості та іiі повноцінної реалізації в сучасному житті» наголошують упорядники сучасних програм [7, с. 5].

Методисти розрізняють «компетенцію», що визначається державою, певною установою, окремими особами, які організовують той чи той вид діяльності, і «компетентність», що набувається в процесі оволодіння знаннями, вміннями, навичками (компетенціями), вказує на здатність і нахил індивіда до виконання певного виду діяльності. Так, щодо шкільного вивчення літератури, «літературною компетенцією» пропонується вважати «інтегрований результат навчальної діяльності, який базується на сукупності знань, отриманих у процесі літературної освіти, і виявлений у вміннях, необхідних для сучасного життя». Під час вивчення української літератури формуються потреби самореалізовуватися, самоогранізовуватися, критично осмислювати інформацію; уміння інтерпретувати художній твір, визначати його естетичну вартість; навички раціональної продуктивної творчої діяльності, оволодіння усним і писемним спілкуванням тощо [8, с. 14; 7, с. 5].

Обмірковуючи проблему професіоналізації, підготовки людини, для якої література стане предметом професійної діяльності, авторитетний дослідник Ю. Кузнецов наголошує: в ідеалі нам треба підготувати письменника або принаймні критика, літературознавця [4, с. 6]. Проте, у вищій педагогічній школі, зокрема під час викладання літератури, пріоритетним $\epsilon$ повідомлення нових знань, вироблення інтересу до теоретичного аналізу (лекційні заняття); практичне засвоєння науково-теоретичних положень; пошук відповідей на окремі літературознавчі питання (практичні, лабораторні заняття); організація науково-дослідної роботи (написання курсових, бакалаврських, магістерських робіт) тощо. Розробка ж науково обгрунтованої системи формування професійно-творчих здібностей студентів-гуманітаріїв $\epsilon$ методичною проблемою. Наприклад, якщо вчені приділяють увагу питанням теорії і методики вивчення студентами різних родів, жанрів, то завдання «навчання творам різних типів $\mathrm{i}$ жанрів, особливо на літературному матеріалі, залишається одним із тих, які викликають занепокоєння, і важким для розв'язання» $[1$, с. 20]. На нашу думку, викладачі рідко пропонують студентам спробувати себе в якості письменника, оскільки поряд із вершинними взірцями класиків їх «творчість» виглядає як реміснича діяльність, графоманство. Автор статті розмірковує, як через практику написання твору малої прозової форми виявляти і розвивати у майбутніх учителів-словесників літературне обдарування, вміння віднаходити певні 
нюанси мистецької реалізації, долаючи деструктивний автоматизм, сліпе i стихійне наслідування стилю митця-професіонала.

Формувати текстотворчі вміння доречно на прикладі написання невеликих прозових творів фантастичного жанру:

- у літературознавстві прийнято вважати новелу школою майстерності прозаїків, «підготовчим класом» (В. Фащенко); науковці, які беруть участь в обговоренні проекту концепції реформування літературної освіти, вмотивовують потребу збільшення «необ’ємних» (В. Мацько) програмових творів, що дозволить краще осмислити поетику новели; підніме престиж жанру;

- методистами науково обгрунтовано, що художня фантастика будить думку, стимулює пошук, є своєрідним каталізатором творчості, заохочує до вдосконалення, що відповідає завданням освіти XXI ст., вимогам побудови суспільства на гуманістичних засадах [5, с. 26];

- фантастика - один із найбільш знаних молоддю, найчитабельніших жанрів літератури; випробовуючи свої сили в ньому, можна стати відомим, отримати визнання, адже постійно оголошуються конкурси для фанів; це i щорічні Міжнародний фестиваль фантастики «Портал», Всеукраїнський фестиваль «Всесвіт Олеся Бердника»; літературні проекти в Інтернеті «Зоряна Фортеця», «Наше Місто», «ЗФ-6», «Галілей» та ін.;

- деякі критики протиставляють фантастичний жанр як «масове», «популярне», «комерційне» чтиво «власне літературним текстам» (Ц. Тодоров, Г. Грабович). Однак популярні письменники-фантасти, як правило, виходять за межі простого відбору і трансформації фольклорноміфологічного матеріалу у світ власного творення; так, в есе «Про чарівні історії» Дж. Р.Р. Толкін проголосив важливість написання фантастики «з великою майстерністю», коли головною іiі чеснотою стає «літературна значущість». Варто згадати і спроби сучасних літературознавців обгрунтувати, що кітч - не завжди втілення «поганого смаку» (Т. Гундорова), а й «певний вид естетизму» (С. Зонтаг), «культурна категорія» (Ж. Бодрійяр) тощо;

- організовувати мистецьку діяльність студентів слід на засадах розвивальних технологій, зокрема розвитку творчої особистості ученого i письменника-фантаста Г. Альтшуллера.

Методист Г. Токмань слушно зауважує: написанню твору художнього характеру (за законами певного белетристичного жанру) має передувати вивчення конкретних художніх прикладів [6, с. 160]. Скористаємося тим, що виклади історії літератури в університеті дають змогу осмислити жанр діахронічно, пропонуємо студентам ознайомитися із творами засновника прози, зокрема і фантастичної, Г. Квітки-Основ’яненка; оповіданнями на українські теми М. Гоголя, які «зробили епоху в російській літературі» (Д. Чижевський); зразками містичної фантастики Н. Кобринської; новелами майстра оніричної техніки М. Яцкова; творами з вкрапленням сюрреалістичних епізодів М. Хвильового; «химерною» прозою В. Шевчука; науковою 
фантастикою В. Бережного, Н. Околітенко; фентезі О. Бердника, В. Билинського, В. Аренєва та інших.

Щоб студенти набули компетентності письменника-фантаста, вони мають оволодіти знаннями 3 теорії фантастичного жанру, зокрема запропонованих програмою (фантастичне, міфологічно-етнографічне, етнографічно-фантастичне, баладне, казково-алегоричне оповідання; оповідання гофманівського типу, оповідання-казка, легенда-оповідання, містична, готична новели, тощо), надсучасних (фентезі, пастиш, кібер-панк, стім-панк, хорор, література меча і чаклунства тощо) жанрових модифікацій, підвидів, різновидів фантастичної прози; уміти розрізняти фантастичну модель та міметичну; фантастику класицистів, романтиків, декадентів, символістів, експресіоністів, сюрреалістів; визначати як домінантний чи рецесивний генологічний чинник, наприклад, у чарівній казці, тваринному епосі, готичному романі, утопії, антиутопії (крім того, що фантастика скомплікований жанр); співвідношення 3 іншими естетичними кодами літератури (міфологізм, філософізм, притчевість, сатиричність) тощо.

Виучувану теорію необхідно пов'язати із практикою, тому пропонуємо студентам виконати ряд завдань. Наприклад, порівняйте твори на одну тему письменників XIX i XXI ст. - Мертвецький Великдень» Г. Квітки-Основ’яненка та «Неспокій» зі збірки «Пентакль» (К., 2004) Марини та Сергія Дяченків, Генрі Лайон Олді, Андрія Валентинова; уточніть зміст поняття «фантастична проза», визначивши константні, репродуктивні та лабільні, змінні, ознаки жанру. Проілюструйте прикладами 3 художніх творів міркування літературознавця М. Яценка, щоестетичне освоєння світу народної фантазії тривалий час поставало жанротвірним чинником української прози. Дослідіть явище української «химерної прози» у контексті творчості представників «магічного реалізму» А. Карпентьєра, Ж. Амаду, М. Астуріаса, Гарсіа Маркеса тощо. Зінтерпретуйте явище жанровості щодо твору В. Билінського «Казка про мертвяка і рибку»; як постмодерний автор використовує властивості симулякру; ваше ставлення до створення окремими літераторами 3 Чорнобильської катастрофи маскультурної фантазії. Студенти з високим рівнем навчальних досягнень можуть взяти участь у дискусії: чи справді процес зростаючої популярності фентезі змінюється його естетичною деградацією (міркування Ю. Шевельова про «перекреслення» ранніх міфологічно-етнографічних спроб П. Куліша «демонстративно-аристократичною «Орисею»; оцінка фахівцями «демонологічних варіацій» пізнього О. Стороженка як «дещо архаїчних» для другої половини XIX ст. (В. Погребенник); «Химерного» стилю прозаїків $\mathrm{XX}$ ст. як «низького», що провокував катастрофу національної прози, оскільки умовність вироджувалася в фальшивість (Н. Збровська) тощо).

За оприлюдненими в Україні результатами досліджень американських науковців, знання найефективніше (до 90 \%) засвоюються не у традиційній практичній діяльності, а через негайне застосування, зокрема навчання одними учнями інших. Тому продовжимо учитися, водночас узагальнимо 
результати вже осмисленого, у формі майстер-класу, уроків письменникамайстра. В ідеалі, це має бути зустріч з митцем; спілкування в режимі онлайн. Аудиторний варіант: підготовлений студент або викладач, на основі опрацьованого розділу «Фантастичне оповідання» 3 теоретичної праці М. Йогансена «Як будується оповідання. Аналіза прозових зразків» [3], імітує класика, формулюючи провідну ідею його досвіду та презентуючи технологію іiі реалізації. У «вступному слові» М. Йогансен пояснить, що хотів звернути увагу читачів на фантастику, зокрема через гостросюжетність як «жанрову домінанту» (Б. Томашевський), що організовує цілісність твору. Адже в українській прозі 20-х років ХХ ст. відчутно домінували експресивні ліричні форми; на знак протесту окремі активісти-прозаїки навіть об'єдналися у групу т.зв «сюжетників». Письменник-професіонал «розбирає» техніку письма класиків жанру, як Г.Дж. Велз, виступаючи з ініціативою створення наукових засад критики та підвищення мистецьких вимог до художніх творів своїх радянських колег, багато з яких $є$ «казенними» письменниками [3, с. 447]. Майстер наведе зразки науково-фантастичних та авантюрнофантастичних оповідань; покаже різницю між «fancy» та «phantasy», тектонікою фабули оповідань «низької» й «вищої» структури; механічною і структурною мотивацією послідовності подій; як зробити твір привабливим «ідеологічно» тощо. «Висновок» художника i науковця: «для того, щоб підняти мистецьку кваліфікацію письменників, потрібна насамперед аналіза техніки творів»; але для довершеності твору слід подбати про філософське наповнення [3, с. 447-448].

Уроки майстер-класу можна підготувати за відомим підручником Т. Хантінгтона «Елементи англійського письменства»; автор повчає аматорів починати писати не з визначення теми, укладання плану (раціо), а 3 пошуку того, що найбільше хвилює, щоб принести в літературу нестримні почуття і живий інтерес; попередньо вивчивши внутрішні пружини творів різних стилів і жанрів; але радить опановувати не «правила» письменства, а «традиції» [4, с. 9].

Перед написанням художнього твору студентам варто виконати ряд вправ: навести приклади «надприродних» фабул, персонажів; фантастичної двозначності, коли читач вагається, події відбуваються насправді, чи тільки наснилися, примарилися герою; «раціоналістичного» й «надприродного» пояснень надзвичайного явища; простої та ускладненої інтриги; комбінування сюжетних елементів за принципом інтерференції фікції й дійсності; виняткових умов дії, хронотопних зміщень; способів участі автора в пригоді; популярних прийомів паралелізму, «асоціації суміжностей», впровадження до розповіді дрібної, малопомітної деталі, на якій фактично тримається сюжет, і яка дає авторові новели нагоду несподіваного, здавалось би, звороту, що І. Качуровський назвав «засобом куріпки» тощо.

Найсміливішим студентам викладач пропонує взяти участь у конкурсах, наприклад, на краще науково-фантастичне оповідання «Галілей» у межах проекту «Наука та інновації - суспільству» (www.galilei.org.ua). 
Отже, оволодіння майбутніми вчителями-словесниками письменницької ключової компетентності сприяє творчому становленню індивідуума; дозволяе гіпотетично відновити мистецьку лабораторію письменника, що підвищує якість вивчення курсу історії української літератури; відповідно ефективність професійної діяльності випускника вищої школи. На часі розроблення методистами науково обгрунтованої системи формування професійно-творчих здібностей студентів-гуманітаріїв.

\section{Література}

1. Гринберг Б. Обучение сочинению-рассуждению на литературную тему как методическая проблема / Б. Гринберг // Проблемы филологического образования : [матер. VII зональной научн.-практ. конфер. «Актуальные проблемы филологического образования: наука-вуз-школа»]. - Екатеринбург : Изд-во АМБ, 2001. - С. 20-23.

2. Зимняя И. Ключевые компетентности - новая парадигми результата образования / И. Зимняя // Высшее образование сегодня. - 2003. - №5. - С. 3-7.

3. Йогансен М. Вибрані твори / Майк Йогансен. - К. : Смолоскип, 2001. - 516 с.

4. Кузнецов Ю. Навчити думати... Ще раз про мету освіти у профільній школі / Юрій Кузнецов // Українська мова й література в середніх школах, гімназіях, ліцеях та колегіумах. - 2007. - №1. - С.4-10.

5. Логвіненко Н. Література мрії i передбачення. Вивчення української фантастичної прози в системі факультативних занять / Н. Логвіненко // Українська література в загальноосвітній школі. - 2009. - №12. - С. 25-28.

6. Токмань Г. Методика викладання української літератури в старшій школі: екзистенціально-діалогічна концепція / Г. Токмань. - К. : Міленіум, 2002. - 320 с.

7. Українська література. 5-12 класи: програма для загальноосвітніх навчальних закладів / за заг. ред. Мовчан Р. В. - К. : Перун, 2005. - 201 с.

8. Фурсова Л. Від літературної компетенції - до життєвої компетентності / Людмила Фурсова // Українська мова й література в середніх школах, гімназіях, ліцеях та колегіумах. - 2005. - №5. - С.12-21.

Стаття надійшла до редакції 12.05.2012 p.

УДК 371.134:371.381

Л. О. Савченко, кандидат пед. наук, доиент, Криворізький педагогічни інститут ДВНЗ «Криворізький начіональний університет»

\section{КОМПЕТЕНТНІСНИЙ КОНЦЕПТ ФОРМУВАННЯ ЯКОСТІ ПІДГОТОВКИ МАЙБУТНІХ УЧИТЕЛІВ} учителів.

Савченко Л. О.Компетентнісний концепт формування якості підготовки майбутніх

У статті розкрито концептуальне тлумачення комптентнісного підходу $і$ специфіки його застосування під час викладання педагогічних дисциплін у вищий школі. Комптентнісний підхід визначається професійними базовими знаннями та вміннями, ціннісними орієнтаціями, мотивами діяльності викладача, розумінням себе і довкілля, стилем взаємин з людьми, загальною культурою, здатністю до розвитку свого творчого потенціалу.

Ключові слова: компетентність, компетенція, компетентнісний підхід. учителей.

Савченко Л. А. Компетентносный конщепт формирования качества подготовки будущих

В статье раскрыты кониептуальное толкование комптентносного подхода и специфики его применения при преподавании педагогических дисциплин в высший школе. Комптентносный 